\title{
Promoting Social Learning in Soil Water and Nutrients Management Using Farmer-Friendly Monitoring Technology ${ }^{\dagger}$
}

\author{
Isaac Rhinnexious Fandika ${ }^{1, *}$, Richard Stirzaker ${ }^{2}$ and Grivin Chipula ${ }^{3}$ \\ 1 Department of Agricultural Research Service, Kasinthula Agricultural Research Station, \\ P.O. Box 28 Chikwawa, Malawi \\ 2 CSIRO Agriculture and Food, GPO Box 1700, Canberra, ACT 2601, Australia; richard.stirzaker@csiro.au \\ 3 The Agricultural Engineering Department, Lilongwe University of Agriculture and Natural Resources, \\ P.O. Box 219 Lilongwe, Malawi; gchipula@luanar.ac.mw \\ * Correspondence: fandika68@gmail.com \\ + Presented at the third International Tropical Agriculture Conference (TROPAG 2019), Brisbane, Australia, \\ 11-13 November 2019.
}

Published: 30 December 2019

\begin{abstract}
Soil water management is typically by trial and error among smallholder farmers. Social learning in the use of farmer - friendly soil-water and nutrients monitoring tools were promoted in Malawi to improve productivity. A simple tool (chameleon) which was designed to fit the mental model of African farmers and to give an output that is linked to action was deployed to 198 farmers in nine irrigation schemes. Chameleon illustrates information on soil moisture status by coloursblue, green and red colours representing adequate moisture, moderate and dry soil status, respectively. The use of colours and not numbers promoted inclusiveness across illiterate and all gender categories. Farmers participated in sensors' installation, soil moisture measurement, data visualization and learning by doing to get insights from their participation. The chameleon was combined with an on-line communication and learning system to improve water management at scheme level. The results indicated that: (1) the tool gave farmers new frames of reference; (2) it improved farmers on time, labour and water saving by reducing irrigation intervals; (3) it gave farmers new reference of experience to change their irrigation traditions; (4) it also reduced conflict for water in irrigation schemes between users apart from improving water productivity. Use of these tools made a rigor that make scientists easily communicate science to lay farmer and initiated the movement of farmers who know how to manage water. Social learning in sensor technology helped to increase farmers' resilience to climate change and shaping the science of the future.
\end{abstract}

Keywords: irrigation; soil moisture; colour; climate change and water management

Funding: Australian Centre for International Agriculture Research (ACIAR)

Acknowledgments: Acknowledge ACIAR Financial Support and Malawi Government support to carryout research. Conflicts of Interest: The authors declare no conflict of interest.

(C) 2019 by the authors. Licensee MDPI, Basel, Switzerland. This article is an open access article distributed under the terms and conditions of the Creative Commons Attribution (CC BY) license (http://creativecommons.org/licenses/by/4.0/). 